\title{
Computational drug repositioning for peripheral arterial disease: prediction of anti-inflammatory and pro-angiogenic therapeutics
}

\author{
Liang-Hui Chu ${ }^{1 *}$, Brian H. Annex ${ }^{2}$ and Aleksander S. Popel ${ }^{1}$ \\ ${ }^{1}$ Department of Biomedical Engineering, School of Medicine, Johns Hopkins University, Baltimore, MD, USA, ${ }^{2}$ Division of \\ Cardiovascular Medicine, Department of Medicine and Robert M. Berne Cardiovascular Research Center, University of \\ Virginia School of Medicine, Charlottesville, VA, USA
}

OPEN ACCESS

Edited by:

Daniel Moura,

University of Porto, Portugal

Reviewed by:

Luis Azevedo,

University of Porto, Portugal Mónica Isa Moreira-Rodrigues,

University of Porto, Portugal

${ }^{*}$ Correspondence:

Liang-Hui Chu,

Department of Biomedical Engineering, School of Medicine, Johns Hopkins University, 720 Rutland Avenue, 613 Traylor Bldg., Baltimore,

MD 21205, USA

chulianghui@gmail.com

Specialty section:

This article was submitted to Cardiovascular and Smooth Muscle

Pharmacology,

a section of the journal

Frontiers in Pharmacology

Received: 23 March 2015 Accepted: 10 August 2015

Published: 25 August 2015

Citation:

Chu L-H, Annex BH and Popel AS

(2015) Computational drug

repositioning for peripheral arterial

disease: prediction of

anti-inflammatory and pro-angiogenic

therapeutics.

Front. Pharmacol. 6:179.

doi: 10.3389/fphar.2015.00179
Peripheral arterial disease (PAD) results from atherosclerosis that leads to blocked arteries and reduced blood flow, most commonly in the arteries of the legs. PAD clinical trials to induce angiogenesis to improve blood flow conducted in the last decade have not succeeded. We have recently constructed PADPIN, protein-protein interaction network (PIN) of PAD, and here we combine it with the drug-target relations to identify potential drug targets for PAD. Specifically, the proteins in the PADPIN were classified as belonging to the angiome, immunome, and arteriome, characterizing the processes of angiogenesis, immune response/inflammation, and arteriogenesis, respectively. Using the network-based approach we predict the candidate drugs for repositioning that have potential applications to PAD. By compiling the drug information in two drug databases DrugBank and PharmGKB, we predict FDA-approved drugs whose targets are the proteins annotated as anti-angiogenic and pro-inflammatory, respectively. Examples of pro-angiogenic drugs are carvedilol and urokinase. Examples of anti-inflammatory drugs are ACE inhibitors and maraviroc. This is the first computational drug repositioning study for PAD.

Keywords: peripheral arterial disease, computational drug repositioning, inflammation, angiogenesis, drug-target network, bioinformatics, cardiovascular disease

\section{Introduction}

Recent pharmaceutical research and development (R\&D) reports show that the probability of success for a new pharmaceutical compound to get to the market has declined in the last 10 years (Pammolli et al., 2011). The average time of drug development has increased from 9.7 years during the 1990 s to 13.9 years from 2000 onwards. The average probability of success of total numbers of $\mathrm{R} \& \mathrm{D}$ projects in the cardiovascular system is only $4.86 \%$. Drug repositioning, new use of old drugs, can shorten the development time and provide solutions for the high cost and declined number of new successful drugs of the pharmaceutical companies (Dudley et al., 2011). Computational repositioning strategies can predict new therapeutic indications for FDA-approved drugs, which then have to undergo clinical trials for the new indication (Belch et al., 2003; Ostchega et al., 2007; Shameer et al., 2015). In this study, we primarily use the network-based approach in computational drug repositioning. 
Peripheral arterial disease (PAD) results from atherosclerosis, the plaque built-up inside the arteries, which blocks the blood flow in the peripheral arteries and most commonly in the arteries that perfuse the legs (Belch et al., 2003; Annex, 2013). Age, diabetes, and cigarette smoking are the major risk factors for the development of PAD (Belch et al., 2003; Ostchega et al., 2007; Annex, 2013). There are 8-12 million people with PAD in the United States (Writing Group et al., 2010). The clinical manifestations of PAD range from patients who do not report leg pain but have a lower functional capacity (approximately $50 \%$ of all PAD subjects) to patients who have intermittent claudication manifested as leg pain with walking/exercise that is relieved with rest (approximately $33-40 \%$ of all PAD subjects) (Hirsch et al., 2006; Norgren et al., 2007). With the goal to increase blood flow around blockages, clinical trials using drugs and gene delivery for therapeutic angiogenesis such as VEGF (vascular endothelial growth factor) gene delivery have been performed for the last two decades but have not been successful.

Hoier et al. showed that there was no difference in basal skeletal muscle VEGF mRNA content before and after passive or active exercise between PAD patients and control (Hoier et al., 2013). However, the basal level of anti-angiogenic protein thrombospondin-1 (TSP1) was remarkably higher in the PAD patients than control groups. They conclude that the antiangiogenic factors dominate the pro-angiogenic factors in PAD patients. The up-regulation of TSP1 has been shown in various gene expression microarray studies of mouse (Chu et al., 2015) and human samples of PAD (Fu et al., 2008; Masud et al., 2012). Currently there are no FDA-approved drugs targeting TSP1. Therefore, the computational drug repositioning approach to predict the drugs targeting other endogenous anti-angiogenic proteins should be helpful for designing clinical trials for therapeutic angiogenesis in PAD.

Inflammation plays an important role in initiation and progression of $\mathrm{PAD}$, and many circulating biomarkers such as matrix metalloproteinases (MMPs) and interleukin are considered as the clinical manifestation of PAD (Signorelli et al., 2014). Atherosclerosis is the dominant cause of many cardiovascular diseases, including myocardial infarction, heart failure, coronary artery disease (CAD), and stroke (Frostegård, 2013). Atherosclerosis is a chronic inflammatory condition. Potential anti-inflammatory treatments in atherosclerosis are reviewed in Frostegård (2013). The interplay between inflammation and endothelial progenitor cells is critical in cardiovascular diseases (Grisar et al., 2011). Combination of anti-inflammatory and pro-angiogenic treatments for PAD was suggested and validated in vivo by Zachman et al. (2014). However, a systematic bioinformatics approach to identify the potential drug repositioning for inhibition of anti-angiogenic and pro-inflammatory proteins for PAD is still lacking.

We previously constructed the PADPIN, protein-protein interaction network (PIN) in PAD that includes angiome, immunome, and arteriome, characterizing the processes of angiogenesis, immune response/inflammation and arteriogenesis, respectively (Chu et al., 2015). We have analyzed several available microarray gene expression datasets from ischemic and non-ischemic muscles in two mouse models of
PAD (in C57BL/6 and BALB/c mouse species) from Hazarika et al. (2013) to identify important genes/proteins in PAD, such as THBS1 (thrombospondin-1), TLR4 (toll-like receptor 4), EphA4 (EPH receptor A4), and TSPAN7 (tetraspanin 7). However, none of the four genes (THBS1, TLR4, EphA4, and TSPAN7) have FDA-approved drugs to target them. Considering the time ( $>10$ years) and cost ( $>\$ 1$ billion) for developing a new drug agent, drug repositioning in PAD offers promise of providing effective therapeutics in shorter time and at lower cost compared to conventional de-novo drug discovery and development. In addition, drug repurposing is an approach of taking agents in development that have achieved adequate safety for one indication but are tested for efficacy in another when safety is already evident.

\section{Materials and Methods}

\section{Resources for Drugs and Drug-target Interactions}

We rely on two major resources for drug information and drug-target, DrugBank 3.0 http://www.drugbank.ca/ (Knox et al., 2011) and Pharmacogenomics Knowledge Base (PharmGKB) http://www.pharmgkb.org/ (Whirl-Carrillo et al., 2012). DrugBank contains extensive omics data, such as pharmacogenomic, pharmacoproteomic, and pharmacometabolomic data. We use DTome (Drug-Target interactome tool) (Sun et al., 2012) to compile all the drugs included in DrugBank 3.0 (Knox et al., 2011), including the approved, experimental, nutraceutical, illicit, and withdrawn drugs. We compile three binary relations in DrugBank from DTome: drug-drug, drug-gene, and drug-target interactions. This compilation provides the rich resources for the potential repositioning or repurposing. By considering the drug safety and development time, we focus on FDA-approved drugs in this study. We compiled the three binary relations from PharmGKB: gene-disease, gene-drug, and gene-gene interactions. The drugtarget interactions were compiled from both DrugBank (Knox et al., 2011) and PharmGKB (Whirl-Carrillo et al., 2012).

\section{Proteins in PADPIN and Therapeutic Angiogenesis in PAD}

Details of the construction of PADPIN, protein-protein interaction (PIN) of PAD in angiogenesis, immune response and arteriogenesis, are described in Chu et al. (2015). The methodology is similar to that used for constructing the global PIN of angiogenesis (angiome) that comprises 1233 proteins and 5726 interactions (Chu et al., 2012). The PIN of immune response (immunome) comprises 3490 proteins and 21,164 interactions. The PIN of arteriogenesis (arteriome) comprises 289 proteins and 803 interactions. The degree of node represents the number of links to a node in the network. The network parameter was calculated by NetworkAnalyzer (Assenov et al., 2008) in Cytoscape (Smoot et al., 2011). We start with the genes listed in the three PINs, to find the interactive drugs from the DrugBank and PharmGKB. Note that in bioinformatics publications, and specifically in protein-protein networks 
publications, the terms "gene" and "protein" are sometimes used interchangeably; while we mostly use "protein" term in this context, we sometime use "gene" to be consistent with previous publications.

\section{List of Anti-angiogenic and Pro-inflammatory Genes}

The activation of a specific biological process can be implemented using two strategies. One is direct activation of the genes involved in positive regulation of that biological process; the other is inhibition of the genes involved in negative regulation of that biological process. Specifically for PAD, to stimulate vascular growth and remodeling and increase the blood flow, we propose inhibition of genes annotated as negative regulation of angiogenesis as a therapeutic approach to stimulating angiogenesis. The rationale for this approach is that numerous clinical trials aimed at stimulating angiogenesis by growth factors such as VEGF-A and FGF-2 have not been successful. We identified 39 anti-angiogenic genes, chosen by Gene Ontology (GO: 0016525) and literature (Chu et al., 2014). The endothelial dysfunction in patients with PAD is characterized by impaired nitric oxide signaling, excessive inflammation and diminished response to angiogenic factors (Annex, 2013). To inhibit the inflammation, we propose inhibition of pro-inflammatory responses as a therapeutic approach for anti-inflammatory treatment of PAD. There are 89 genes classified in positive regulation of inflammatory response (GO:0050729). We list these genes in Table 1.

\section{Results}

\section{Drug-targets Relations in Angiome, Immunome and Arteriome of PADPIN}

We collected 11,043 binary relations between the drug and drug targets from DrugBank 3.0 (Knox et al., 2011) and 3138 binary relations between the drug and associated genes of that drug, which may not be the direct targets, from PharmGKB (Whirl-Carrillo et al., 2012). By matching the genes in angiome, immunome, and arteriome with the drug targets listed in the drug-gene binary relations from DrugBank and PharmGKB, we build the complete tables of genes and repositioning drugs (Tables S1-S3). Table S1 shows 409 and 174 drug targets listed in angiome for the drugs from DrugBank and PharmGKB, respectively. We select the genes with at least one drug targeting that gene in angiome, and skip the genes without any drug-gene relations. There might be multiple drugs targeting the same drug target; we list the multiple drugs in the same row of the table. Table S2 shows 865 and 382 drug targets in immunome for the drugs from DrugBank and PharmGKB, respectively. Table S3 shows 82 and 46 drug targets in arteriome for the drugs from DrugBank and PharmGKB, respectively.

We rank the genes in angiome, immunome, and arteriome by the degree of nodes, i.e., number of links of the nodes in the network, in Tables S1-S3, respectively. Tables S1-S3 provide the complete list of drugs and drug targets which are annotated in angiogenesis, immune response/inflammation, and arteriogenesis. Tables $\mathrm{S} 1-\mathrm{S} 3$ provide the complete list of drugs in DrugBank and PharmGKB, including approved, experimental, nutraceutical, illicit, and withdrawn drugs. Considering the drug safety and efficacy issues, we mostly consider the FDA-approved drugs in the predictions of repositioning drugs (Table S4).

\section{Inhibition of Anti-angiogenic Pro-inflammatory Genes}

We postulate two strategies to the PAD treatment: proangiogenic and anti-inflammatory. Starting from the 39 genes annotated in negative regulation of angiogenesis (see Materials and Methods), we match the genes with drug targets and drugs listed in Table S1, and only list the FDA-approved drugs from DrugBank in Table 2. The five genes are CCL2, NPPB, NPR1, PF4, and SERPINE1. These drugs include mimosine targeting CCL2, carvedilol targeting NPPB, nitroprusside targeting NPR1, urokinase, reteplase, and drotrecogin alfa targeting SERPINE1. The beta-blockers (e.g., carvedilol in our prediction) in general have not been shown to affect PAD symptoms, but they do not make PAD symptoms worse (Paravastu et al., 2013). Infusion of recombinant-based plasminogen activator (e.g., reteplase) and urokinase can clear blood clots and restore blood

TABLE 1 | List of 39 anti-angiogenic and 89 pro-inflammatory genes.

\begin{tabular}{lll}
\hline Categories & Gene ontology & List of genes \\
\hline Anti-angiogenic & Negative regulation of angiogenesis (GO: 0016525) & AMOT, ANGPT2, APOH, BAl1, CCL2, CCR2, COL4A2, COL4A3, CXCL10, FASLG, \\
& FOXO4, GHRL, GTF2, HDAC5, HHEX, HOXA5, HRG, KLF4, KLK3, KRIT1, LECT1, LIF, \\
& MAP2K5, NF1, NPPB, NPR1, PDE3B, PF4, PML, PTPRM, ROCK1, ROCK2, \\
& SERPINE1, SERPINF1, STAB1, THBS1, THBS2, THBS4, TIE1
\end{tabular}

Pro-inflammatory Positive regulation of inflammatory response (GO:0050729)
ACE, ADAM8, ADORA2B, ADORA3, AGER, AGT, AGTR1, ALOX5AP, AOC3, C3, CCL24, CCL3, CCL3L3, CCL5, CCR2, CCR5, CCR7, CD28, CD47, CLOCK, CNR1, CTSS, CX3CL1, EDNRA, EGFR, FABP4, FCER1A, FCER1G, FCGR1A, FCGR2A, FFAR3, GPRC5B, HSPD1, HYAL2, IDO1, IL12B, IL15, IL18, IL1B, IL1RL1, IL2, IL21, IL23A, IL33, IL6, IL6ST, ITGA2, JAK2, LBP, LTA, MAPK13, MIF, NLRP12, NPY5R, OSM, OSMR, PDE2A, PDE5A, PIK3CG, PLA2G2A, PLA2G4A, PLA2G7, PRKCA, PTGER3, PTGER4, PTGS2, RPS19, S100A12, S100A8, S100A9, SERPINE1, STAT5A, STAT5B, TAC1, TGM2, TLR2, TLR3, TLR4, TLR7, TLR9, TLR10, TNF, TNFRSF11A, TNFRSF1A, TNFSF11, TNFSF4, TNIP1, WNT5A, ZP3 
TABLE 2 | Predictions of pro-angiogenic FDA-approved drugs that target anti-angiogenic genes.

\begin{tabular}{|c|c|c|c|}
\hline Gene symbol & Gene name & DrugBank & Physiological relevance in PAD or CAD \\
\hline CCL2 & Chemokine (C-C motif) ligand 2 & Mimosine, danazol & $\begin{array}{l}\text { Potential indicator of atherosclerosis in PAD } \\
\text { (Rull et al., 2011) }\end{array}$ \\
\hline NPPB & Natriuretic peptide B & Carvedilol & $\begin{array}{l}\text { Three SNPs at NPPB locus associated with } \\
\text { lower risk of PAD (Hu et al., 2013) }\end{array}$ \\
\hline NPR1 & Natriuretic peptide receptor 1 & $\begin{array}{l}\text { Nitroprusside, nitroglycerin, isosorbide dinitrate, } \\
\text { amyl nitrite, erythrityl tetranitrate, nesiritide }\end{array}$ & \\
\hline PF4 & Platelet factor 4 & Drotrecogin alfa & $\begin{array}{l}\text { PF4 level increasing in patients with coronary } \\
\text { artery ectasia (Yasar et al., 2007) }\end{array}$ \\
\hline SERPINE1 & $\begin{array}{l}\text { Serpin peptidase inhibitor, clade E (nexin, } \\
\text { plasminogen activator inhibitor type 1), member } 1\end{array}$ & $\begin{array}{l}\text { Alteplase, urokinase, reteplase, anistreplase, } \\
\text { tenecteplase, drotrecogin alfa }\end{array}$ & $\begin{array}{l}\text { Plasminogen activator inhibitor-1 (PAl-1) } \\
\text { increasing in patients with CLI (critical limb } \\
\text { ischemia), leading to prothrombotic (Björck } \\
\text { et al., 2013) }\end{array}$ \\
\hline
\end{tabular}

flow in occluded blood vessels of patients with diseases such as myocardial infarction and PAD (Lippi et al., 2013). The mechanism of mimosine targeting CCL2 in PAD is not clear.

These anti-angiogenic proteins may not have direct physiological relevance in PAD. We use PubMed by searching the keywords "(Gene symbol) AND (PAD OR coronary arterial disease)" to find the relevant literature in the recent 10 years (2005-2015) for the five genes in PAD. These references support the potential biomarkers or drug targets of the five anti-angiogenic proteins in PAD, such as CCL2 (Rull et al., 2011), NPPB (Hu et al., 2013), and SERPINE1 (Yasar et al., 2007). However, these references do not link the anti-angiogenic properties of these genes to PAD. Thus, the concept of inhibition of anti-angiogenic proteins in PAD is novel and should be further explored.

\section{Inhibition of Pro-inflammatory Genes}

We match the 89 pro-inflammatory genes with drug targets and drugs listed in Table S2, and only list the FDA-approved drugs from DrugBank in Table 3 (see the list of pro-inflammatory genes in Methods). The corresponding FDA-approved drugs include maraviroc (an antiretroviral drug, a CCR5 inhibitor), bosentan (a dual endothelin receptor antagonist that affects both endothelin $A$ and $B$ receptors, used in the treatment of pulmonary artery hypertension), sitaxentan (endothelin A receptor antagonist, used in the treatment of pulmonary artery hypertension), cetuximab (EGFR antagonist, used in several types of cancer) and imiquimod (an immune response modulator, used for skin diseases including skin cancer).

To find the physiological relevance of these pro-inflammatory genes in PAD, we continue to use PubMed to find the relevant references. References in Table 3 support our hypothesis that anti-inflammatory drugs have high potential for repositioning for PAD. Some drugs cannot improve ABI (ankle-pressure index) of PAD patients but can improve the walking ability in patients with critical limb ischemia (CLI), such as ACE inhibitors (Hunter et al., 2013; Shahin et al., 2013). Some genes are indicated as related with $\mathrm{PAD}$, such as $\mathrm{C} 3$ (complement component 3) (Fehervari et al., 2014), PTGS2 (prostaglandinendoperoxide synthase 2) (Flórez et al., 2009), SERPINE1
(Björck et al., 2013), S100A12 (Shiotsu et al., 2011), and TNF (Botti et al., 2012; Wozniak et al., 2012; Gardner et al., 2014). Some genes are potential biomarkers or associated with other cardiovascular diseases, such as AGTR1 (angiotensin II receptor, type 1 ) in coronary occlusive disease (Baños et al., 2011), CCR5 in pulmonary arterial hypertension (Amsellem et al., 2014), LTA (lymphotoxin alpha) in CAD (Topol et al., 2006), and PRKCA (protein kinase C, alpha) in atherosclerosis (Konopatskaya and Poole, 2010). Many of the anti-inflammatory genes in Table 3 are not directly associated with PAD or CAD based on PubMed search, such as ADORA2B (adenosine A2b receptor), EDNRA (endothelin receptor type A), FCER1G (Fc receptor, IgE, high affinity I, gamma polypeptide), STAT5B (signal transducer and activator of transcription 5B), and TLR9 (toll-like receptor 9). In general, the physiological evidence of these anti-inflammatory genes listed in Table 3 strongly supports our hypothesis that inhibition of pro-inflammatory genes is a viable drug repositioning strategy in PAD.

\section{Visualization of Drug-target Network}

Graph representation is used to visualize pro-angiogenic and anti-inflammatory repositioning drugs for PAD in Figures 1, 2, respectively. We plot the drug-target networks of the antiangiogenic and pro-inflammatory proteins for the drugs in Tables 2, 3, respectively. We represent the drug target by pink circle and the drug by blue square. Figure 1 shows several compounds targeting the proteins which are annotated as negative regulation of angiogenesis. Figure 2 shows the drugtarget networks of the anti-inflammatory drugs and targets from Table 3. The number of inflammation targets and drugs in Figure 2 is much larger than anti-angiogenic targets and drugs in Figure 1. This gives the insight for the development of clinical trials of anti-inflammatory drugs in PAD in the future. We will discuss the potential clinical trials in Discussion.

\section{Discussion}

The clinical trials aimed at stimulating VEGF in PAD and CAD have been unsuccessful (Annex, 2013). The exercise therapy has been demonstrated as the beneficial treatment 
TABLE 3 | Predictions of anti-inflammatory FDA-approved drugs that target pro-inflammatory genes.

\begin{tabular}{llll}
$\begin{array}{l}\text { Gene } \\
\text { symbol }\end{array}$ & Description & DrugBank & Physiological relevance in PAD or CAD \\
\hline ACE & Angiotensin I converting enzyme & $\begin{array}{l}\text { Ramipril, fosinopril, trandolapril, benazepril, } \\
\text { enalapril, candoxatril, moexipril, lisinopril, }\end{array}$ & $\begin{array}{l}\text { ACE inhibitor helping the walking ability in } \\
\text { patients with CLI, but not improving ABI } \\
\text { (ankle-pressure index) (Hunter et al., 2013; } \\
\end{array}$ \\
& $\begin{array}{l}\text { perindopril, quinapril, rescinnamine, captopril, } \\
\text { cilazapril, spirapril }\end{array}$ & Shahin et al., 2013)
\end{tabular}

\begin{tabular}{|c|c|c|c|}
\hline ADORA2B & Adenosine $\mathrm{A} 2 \mathrm{~b}$ receptor & $\begin{array}{l}\text { Theophylline, adenosine, enprofylline, } \\
\text { defibrotide }\end{array}$ & \\
\hline AGTR1 & Angiotensin II receptor, type 1 & $\begin{array}{l}\text { Valsartan, olmesartan, losartan, candesartan, } \\
\text { eprosartan, telmisartan, irbesartan, forasartan, } \\
\text { saprisartan, tasosartan }\end{array}$ & $\begin{array}{l}\text { Correlation between the increased AGTR1 } \\
\text { and cardiovascular risk factors (Baños } \\
\text { et al., 2011) }\end{array}$ \\
\hline AOC3 & Amine oxidase, copper containing 3 & Phenelzine, hydralazine & \\
\hline
\end{tabular}

\begin{tabular}{|c|c|c|c|}
\hline CCR5 & Chemokine (C-C motif) receptor 5 & Maraviroc & $\begin{array}{l}\text { A treatment target in pulmonary arterial } \\
\text { hypertension (Amsellem et al., 2014) }\end{array}$ \\
\hline CNR1 & Cannabinoid receptor 1 (brain) & Dronabinol, nabilone, rimonabant, dronabinol & \\
\hline EDNRA & Endothelin receptor type A & Bosentan, sitaxentan & \\
\hline EGFR & Epidermal growth factor receptor & $\begin{array}{l}\text { Cetuximab, trastuzumab, lidocaine, gefitinib, } \\
\text { erlotinib, lapatinib, panitumumab }\end{array}$ & \\
\hline FCER1A & $\begin{array}{l}\text { Fc fragment of IgE, high affinity I, receptor for; alpha } \\
\text { polypeptide }\end{array}$ & Omalizumab, benzylpenicilloyl polylysine & \\
\hline FCER1G & Fc receptor, IgE, high affinity I, gamma polypeptide & Benzylpenicilloyl polylysine & \\
\hline FCGR1A & Fc fragment of lgG, high affinity la, receptor (CD64) & $\begin{array}{l}\text { Cetuximab, etanercept, intravenous } \\
\text { immunoglobulin, adalimumab, abciximab, } \\
\text { gemtuzumab ozogamicin, trastuzumab, } \\
\text { rituximab, basiliximab, muromonab, } \\
\text { ibritumomab, tositumomab, alemtuzumab, } \\
\text { alefacept, efalizumab, natalizumab, } \\
\text { palivizumab, daclizumab, bevacizumab, } \\
\text { porfimer }\end{array}$ & \\
\hline
\end{tabular}

\section{FCGR2A FC fragment of IgG, low affinity lla, receptor (CD32) Cetuximab, etanercept, intravenous} immunoglobulin, adalimumab, abciximab, gemtuzumab ozogamicin, trastuzumab, rituximab, basiliximab, muromonab, ibritumomab, tositumomab, alemtuzumab, alefacept, efalizumab, natalizumab, palivizumab, daclizumab, bevacizumab

\begin{tabular}{|c|c|c|c|}
\hline IL6 & Interleukin 6 & Ginseng & $\begin{array}{l}\text { Phase III clinical trial targeting IL-6 by } \\
\text { tocilizumab in cardiovascular disease } \\
\text { (Ridker and Lüscher, 2014) }\end{array}$ \\
\hline LTA & Lymphotoxin alpha & Etanercept & $\begin{array}{l}\text { Implicated in predisposition for heart } \\
\text { attack by genome-wide association } \\
\text { studies (GWAS) (Topol et al., 2006) }\end{array}$ \\
\hline
\end{tabular}


TABLE 3 | Continued

\begin{tabular}{|c|c|c|}
\hline $\begin{array}{l}\text { Gene } \\
\text { symbol }\end{array}$ & Description & DrugBank \\
\hline PDE5A & phosphodiesterase 5A, cGMP-specific & $\begin{array}{l}\text { Sildenafil, theophylline, pentoxifylline, tadalafil, } \\
\text { vardenafil, dipyridamole, udenafil }\end{array}$ \\
\hline PLA2G2A & Phospholipase A2, group IIA (platelets, synovial fluid) & $\begin{array}{l}\text { Indomethacin, diclofenac, ginkgo biloba, } \\
\text { suramin, ginkgo biloba }\end{array}$ \\
\hline PLA2G4A & $\begin{array}{l}\text { Phospholipase A2, group IVA (cytosolic, } \\
\text { calcium-dependent) }\end{array}$ & Fluticasone propionate, quinacrine \\
\hline PRKCA & Protein kinase $\mathrm{C}$, alpha & Phosphatidylserine, vitamin $\mathrm{E}$ \\
\hline PTGER3 & Prostaglandin E receptor 3 (subtype EP3) & Bimatoprost, dinoprostone, misoprostol \\
\hline PTGS2 & $\begin{array}{l}\text { Prostaglandin-endoperoxide synthase } 2 \\
\text { (prostaglandin G/H synthase and cyclooxygenase) }\end{array}$ & $\begin{array}{l}\text { Gamma-homolinolenic acid, icosapent, } \\
\text { aminosalicylic acid, mesalazine, } \\
\text { acetaminophen, indomethacin, nabumetone, } \\
\text { ketorolac, tenoxicam, lenalidomide, celecoxib, } \\
\text { tolmetin, piroxicam, fenoprofen, diclofenac, } \\
\text { sulindac, flurbiprofen, etodolac, mefenamic } \\
\text { acid, naproxen, sulfasalazine, phenylbutazone, } \\
\text { meloxicam, carprofen, diflunisal, suprofen, } \\
\text { salicyclic acid, meclofenamic acid, } \\
\text { acetylsalicylic acid, bromfenac, oxaprozin, } \\
\text { ketoprofen, balsalazide, thalidomide, ibuprofen, } \\
\text { lumiracoxib, magnesium salicylate, } \\
\text { salicylate-sodium, salsalate, } \\
\text { trisalicylate-choline, ginseng, antrafenine, } \\
\text { antipyrine, tiaprofenic acid, etoricoxib, niflumic } \\
\text { acid, lornoxicam, nepafenac, } \\
\text { gamma-homolinolenic acid, icosapent, } \\
\text { ginseng, thalidomide }\end{array}$ \\
\hline
\end{tabular}

Physiological relevance in PAD or CAD

\begin{tabular}{|c|c|c|c|}
\hline S100A12 & S100 calcium binding protein A12 & Olopatadine, amlexanox & $\begin{array}{l}\text { The potential biomarker for chronic arterial } \\
\text { disease (Saito et al., 2012) and associated } \\
\text { with PAD (Shiotsu et al., 2011) }\end{array}$ \\
\hline
\end{tabular}

\begin{tabular}{lll}
\hline SERPINE1 & $\begin{array}{l}\text { Serpin peptidase inhibitor, clade E (nexin, } \\
\text { plasminogen activator inhibitor type 1), member } 1\end{array}$ & $\begin{array}{l}\text { Alteplase, urokinase, reteplase, anistreplase, } \\
\text { tenecteplase, drotrecogin alfa }\end{array}$
\end{tabular}

The key protein in regulation of platele function and thrombosis in arteries (Konopatskaya and Poole, 2010)

PDE5 inhibition promotes ischemia-induced angiogenesis (Sahara et al., 2010)

PTGS2 (COX2) inhibition improves inflammation and endothelial dysfunction in PAD patients with intermittent claudication (IC) (Flórez et al., 2009) with PAD (Shiotsu et al., 2011)

\begin{tabular}{|c|c|c|c|}
\hline & plasminogen activator inhibitor type 1), member 1 & tenecteplase, drotrecogin alfa & $\begin{array}{l}\text { (PAl-1) increased in patients with CLI } \\
\text { (critical limb ischemia) (Björck et al., 2013) }\end{array}$ \\
\hline STAT5B & Signal transducer and activator of transcription 5B & Dasatinib & \\
\hline TLR2 & Toll-like receptor 2 & Ospa lipoprotein & $\begin{array}{l}\text { TLR2 and TLR4 expression increase } \\
\text { during atherosclerosis, but only TLR4 } \\
\text { gene expression associated with PAD } \\
\text { (Varela et al., 2015) }\end{array}$ \\
\hline TLR7 & Toll-like receptor 7 & Imiquimod, hydroxychloroquine & \\
\hline TLR9 & Toll-like receptor 9 & Chloroquine, hydroxychloroquine & \\
\hline TNF & Tumor necrosis factor & $\begin{array}{l}\text { Etanercept, adalimumab, infliximab, } \\
\text { chloroquine, thalidomide, glucosamine, } \\
\text { clenbuterol, pranlukast, amrinone, thalidomide }\end{array}$ & $\begin{array}{l}\text { Circulating TNF higher in PAD patients } \\
\text { than control (Gardner et al., 2014); } \\
\text { Circulating cytokines induce endothelial } \\
\text { dysfunction in PAD patients (Botti et al., } \\
\text { 2012); Negative correlation between TNF } \\
\text { concentration and pain free walking } \\
\text { distance (Wozniak et al., 2012) }\end{array}$ \\
\hline
\end{tabular}

\begin{tabular}{ll}
\hline TNFSF11 Tumor necrosis factor (ligand) superfamily, & Lenalidomide \\
member 11 &
\end{tabular}



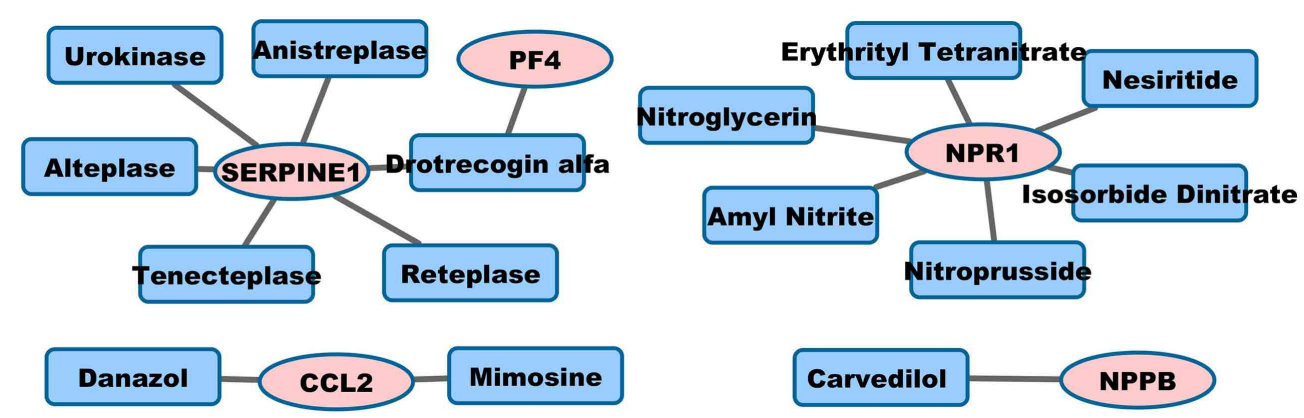

FIGURE 1 | Pro-angiogenic drug-target interaction networks.

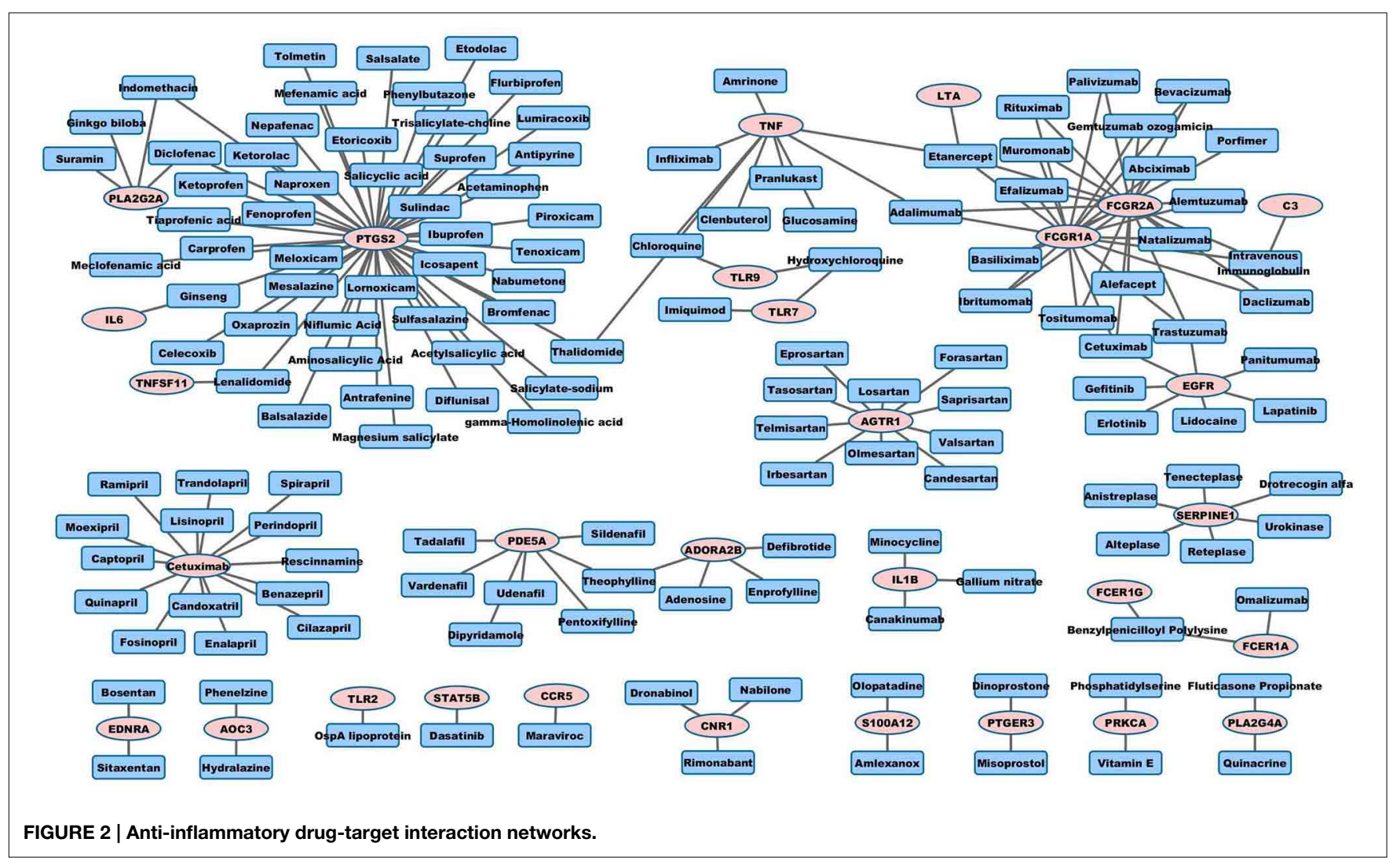

for $\mathrm{PAD}$, including walking tolerance, modified inflammatory markers, and adaptation of the limb (e.g., angiogenesis and arteriogenesis) (Haas et al., 2017). Clinical trials with agents targeting angiogenesis and inflammation, other than stimulation of VEGF, should be considered in the future. Below we provide insights for the potential repositioning drugs in PAD identified in this study, including the mechanism of action of these drugs, case studies for several selected drugs in clinical trials, and future experimental validations.

\section{Mechanism of Action of Repositioning Drugs for PAD}

Tables 1, 2 provide the anti-angiogenic and pro-inflammatory genes/proteins, drugs targeting these molecules, and physiological evidence for the involvement of these molecules in PAD. However, even though these drug-targets have been identified by our bioinformatics approaches, the mechanism of action of these drugs in PAD and the feasibility of the clinical trials need to be elucidated. Specifically, the effect of some of these drugs to promote angiogenesis in PAD by targeting anti-angiogenic proteins is unknown. Therefore, we search PubMed for the drugs listed in Table 2 using the keywords "(drug name) AND angiogenesis" to understand the mechanism and original use of these putative proangiogenic drugs. We list the drugs with at least one supporting reference found in PubMed in Table 4. These drugs include beta-1 adrenergic receptors blocker (carvedilol, targeting NPPB), vasodilator (isosorbide dinitrate, targeting 
TABLE 4 | Mechanism of Action and original use of the drugs for repositioning as pro-angiogenic in PAD.

\begin{tabular}{|c|c|c|c|c|c|}
\hline Drug name & $\begin{array}{l}\text { Target in } \\
\text { angiogenesis }\end{array}$ & $\begin{array}{l}\text { Degree of target } \\
\text { in angiome }\end{array}$ & Mechanism of action & Original use & PubMed search \\
\hline Alteplase & SERPINE1 & 14 & Plasminogen activator & Acute ischemic stroke & $\begin{array}{l}\text { Lapchak and Araujo, 2007; } \\
\text { Hacke et al., } 2008\end{array}$ \\
\hline Danazol & CCL2 & 12 & $\begin{array}{l}\text { Synthetic steroid with antigonadotropic and } \\
\text { anti-estrogenic activities }\end{array}$ & Endometriosis & $\begin{array}{l}\text { Thomas et al., 2007; Szubert } \\
\text { et al., } 2014\end{array}$ \\
\hline Nitroprusside & NPR1 & 4 & $\begin{array}{l}\text { A source of nitric oxide, a potent peripheral } \\
\text { vasodilator }\end{array}$ & Hypertensive emergency & $\begin{array}{l}\text { Ziche et al., 1994; Pyriochou } \\
\text { et al., } 2007\end{array}$ \\
\hline Isosorbide dinitrate & NPR1 & 4 & Vasodilator & Angina pectoris & Goertz et al., 2011 \\
\hline Nesiritide & NPR1 & 4 & Recombinant form of brain natriuretic peptide & Heart failure & Shmilovich et al., 2009 \\
\hline Carvedilol & NPPB & 3 & $\begin{array}{l}\text { Beta- } 1 \text { and beta- } 2 \text { adrenergic receptors } \\
\text { blocker }\end{array}$ & Congestive heart failure & Le et al., 2013; Stati et al., 2014 \\
\hline
\end{tabular}

NPR1), and plasminogen activator (alteplase, targeting SERPINE1).

We further search PubMed for the anti-inflammatory drugs in Table 3 using the keywords "(drug name) AND inflammation" to elucidate the mechanism and original use of these antiinflammatory drugs (Table 5). These drugs include antiplatelet (abciximab targeting FCGR1A, acetylsalicylic acid targeting PTGS2), monoclonal antibody (adalimumab targeintg TNFalpha), immune suppressant (alefacept targeting FCGR1A and FCGR2A), ACE inhibitor (benazepril, captopril and enalapril), non-steroidal anti-inflammatory drug (NSAID, e.g., bromfenac, celecoxib, diclofenac, ketorolac, nepafenac, sulindac), and PDE5 inhibitor (tadalafil, vardenafil).

\section{Case Studies of Potential Drug Targets and Drug Repositioning in PAD}

We choose three candidate drugs for repositioning in PAD as case studies of our predictions. We selected several drugs that are anti-inflammatory or pro-angiogenic and had no effects on each other. These drugs include bosentan, carvedilol, and maraviroc. We compared the drug targets with the up-regulated genes in the microarray dataset of PAD, including the mouse data of Hazarika et al. (2013), and human microarray studies of Masud et al. (2012), Fu et al. (2008), and Croner et al. (2012).

\section{Case I: Bosentan Targeting EDNRA}

The endothelin receptor antagonists (bosentan and ambrisentan) have been approved for use in pulmonary arterial hypertension (PAH) and have been assigned orphan drug status. Details of hepatotoxicity of bosentan, ambrisentan, and sitaxentan are reviewed in de Haro Miralles et al. (2010). Endothelin-1 is a powerful endogenous vasoconstrictor (Frumkin, 2012) and thus blocking endothelin could improve perfusion to the lower extremities in patients with PAD. In a pre-clinical PAD model, Luyt et al. (2000) demonstrated that endothelin, antagonists, bosentan, and darusentan (LU13525) increased tissue blood flow measured by laser Doppler perfusion imaging. de Haro Miralles et al. (2010) examined plasma levels of endothelin and showed that endothelin levels were increased in patients with intermittent claudication compared to non-PAD controls. Just as importantly patients with the most severe form of PAD, CLI, did not demonstrate elevated levels of endothelin, which suggests that an elevation of endothelin is specific to the pathophysiology of intermittent claudication and not all forms of PAD. The original indication of zibotentan was in oncology and pulmonary artery hypertension. The reuse of an endothelin receptor antagonists in PAD patients with intermittent claudication is now in a Phase II clinical trial; the details of the clinical trial of zibotentan are provided in ClinicalTrials.gov https://clinicaltrials.gov/ct2/show/ NCT01890135?term=NCT01890135\&rank=1.

\section{Case II: Carvedilol Targeting NPPB}

Carvedilol has anti-inflammatory and pro-angiogenic effects in chronic ischemic cardiomyopathy (Le et al., 2013). Carvedilol showed improvement of myocardial flow and reduction of inflammation in the canine model of multivessel cardiomyopathy. The anti-inflammatory cytokine IL-10, which inhibits inflammatory cytokines such as TNF $\alpha$, IL-1, IL-6, IL-8, and IL-12, was up-regulated in the carvedilol-treated animals. In the PAD microarray data, the inflammatory cytokine IL-8 was up-regulated as found in Masud et al. (2012) and Croner et al. (2012). Though beta-blockers are commonly used in patients with $\mathrm{PAD}$, currently there are no specific clinical trials for carvedilol being compared to placebo or other beta-blockers in PAD patients.

\section{Case III: Maraviroc Targeting CCR5}

Maraviroc is an HIV drug targeting CCR5, which is involved in the inflammation pathway (Francisci et al., 2014). Therefore, maraviroc could have anti-inflammatory and anti-atherosclerosis effects, and become a potential repositioning drug in PAD. Croner et al. (2012) show the up-regulation of CCR5 in microarrays from the human femoral artery in PAD. CCR5 inhibitor maraviroc also blocks cell migration and metastasis, but not directly affects the angiogenesis pathway in triple negative breast cancer cell lines (Lee et al., 2014). Currently there are no clinical trials for maraviroc in PAD patients.

\section{Limitations of Computational Drug Repositioning Approaches}

There are several limitations by the computational approaches to predict the repositioning drugs in PAD. First, PAD is a 


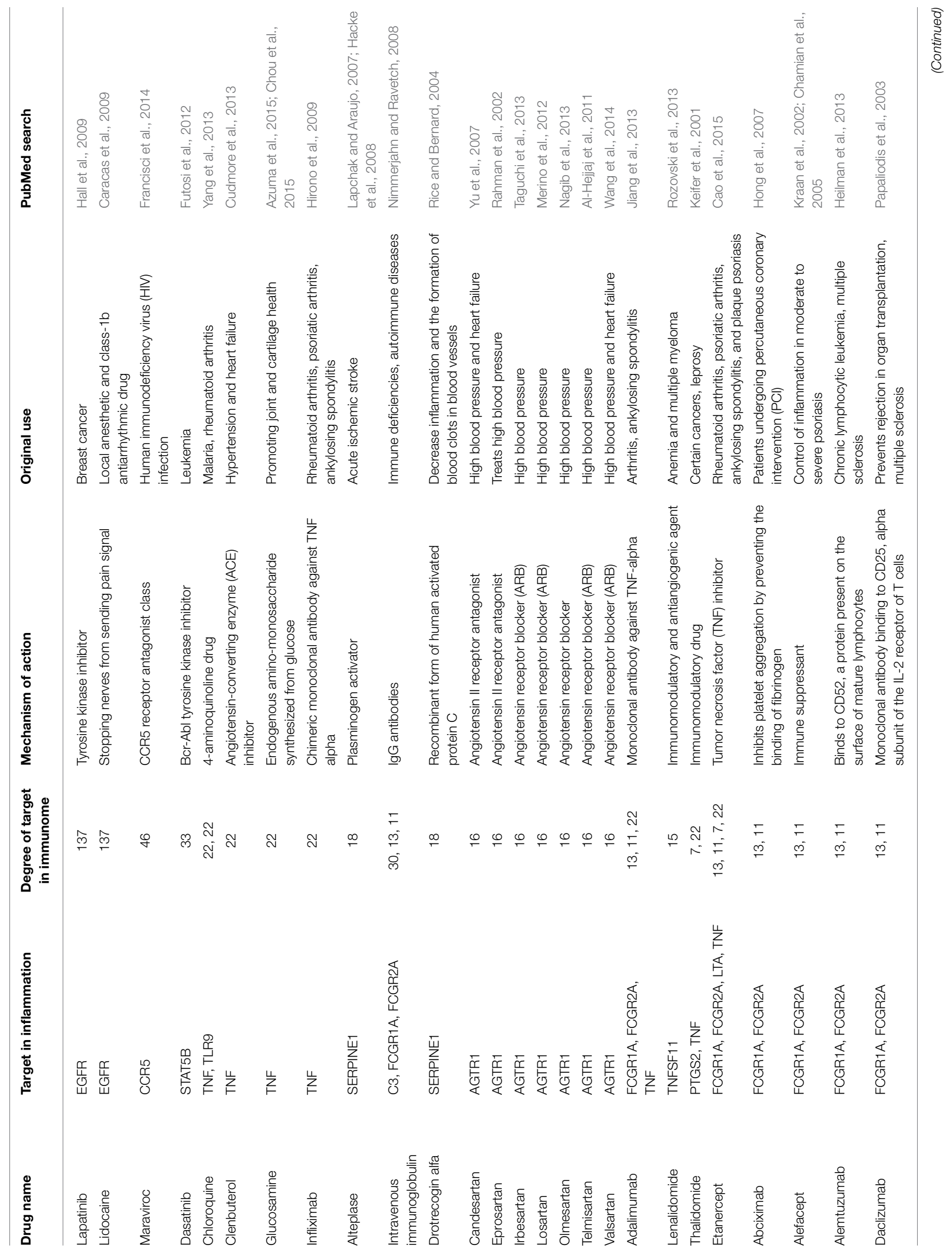




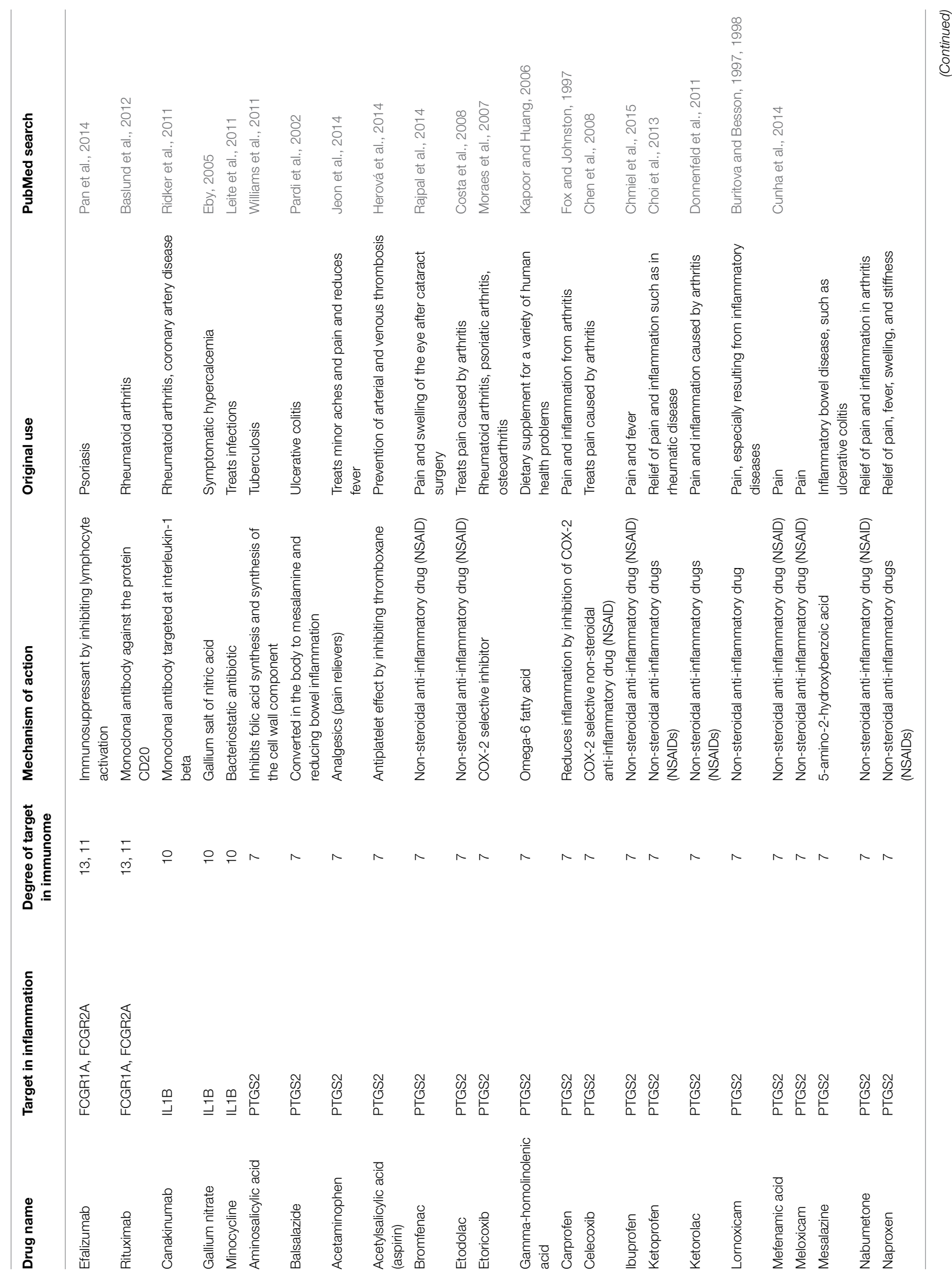




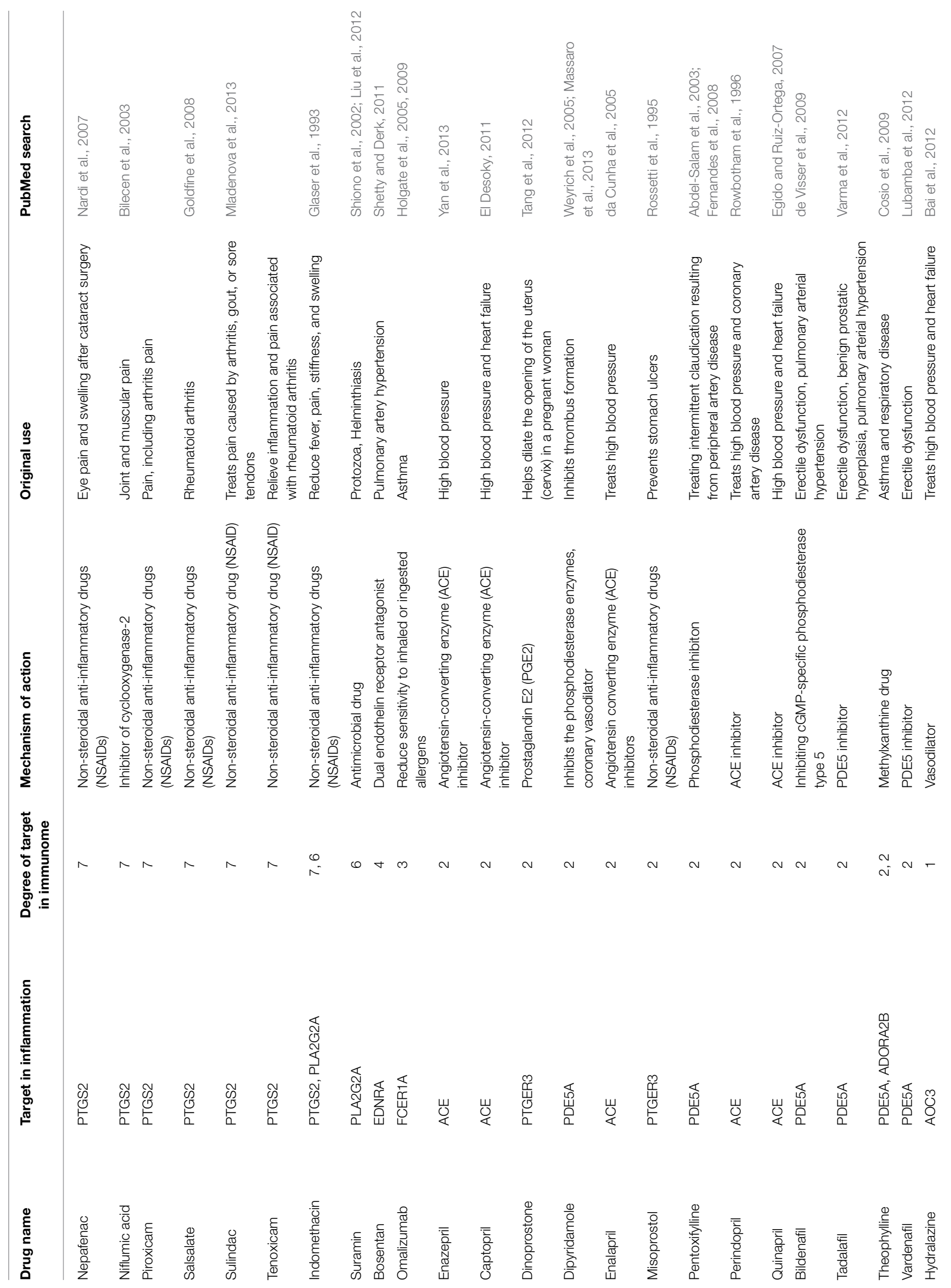


complex disease caused by many risk factors and classified by different stages of diseases. Our methods cannot predict the repositioning drugs based on various conditions in PAD patients. Second, the current available clinical trials based on these predicted repositioning drugs in PAD patients are very limited. The available gene expression dataset in human PAD and mouse PAD model is limited. It is difficult to validate our predictions by current clinical trials and available microarray data. Third, the pro-angiogenic and anti-inflammatory drugtarget networks cannot directly link the drugs to PAD based on the current physiological evidence in PAD. The value of the computational drug repositioning might be limited for clinical trial design.

\section{Conclusions}

Our study provides comprehensive predictions of potential proangiogenic and anti-inflammatory drugs and drug targets for

\section{References}

Abdel-Salam, O. M., Baiuomy, A. R., El-Shenawy, S. M., and Arbid, M. S. (2003). The anti-inflammatory effects of the phosphodiesterase inhibitor pentoxifylline in the rat. Pharmacol. Res. 47, 331-340. doi: 10.1016/S1043-6618(03)00002-1

Al-Hejjaj, W. K., Numan, I. T., Al-Sa'ad, R. Z., and Hussain, S. A. (2011). Antiinflammatory activity of telmisartan in rat models of experimentally-induced chronic inflammation: comparative study with dexamethasone. Saudi Pharm. J. 19, 29-34. doi: 10.1016/j.jsps.2010.10.004

Amsellem, V., Lipskaia, L., Abid, S., Poupel, L., Houssaini, A., Quarck, R., et al. (2014). CCR5 as a treatment target in pulmonary arterial hypertension. Circulation 130, 880-891. doi: 10.1161/CIRCULATIONAHA.114.010757

Annex, B. H. (2013). Therapeutic angiogenesis for critical limb ischaemia. Nat. Rev. Cardiol. 10, 387-396. doi: 10.1038/nrcardio.2013.70

Assenov, Y., Ramírez, F., Schelhorn, S. E., Lengauer, T., and Albrecht, M. (2008). Computing topological parameters of biological networks. Bioinformatics 24, 282-284. doi: 10.1093/bioinformatics/btm554

Azuma, K., Osaki, T., Kurozumi, S., Kiyose, M., Tsuka, T., Murahata, Y., et al. (2015). Anti-inflammatory effects of orally administered glucosamine oligomer in an experimental model of inflammatory bowel disease. Carbohydr. Polym. 115, 448-456. doi: 10.1016/j.carbpol.2014.09.012

Bai, L., Wang, W., Dong, Y. L., Wang, W., Huang, J., Wang, X. Y., et al. (2012). Attenuation of mouse somatic and emotional inflammatory pain by hydralazine through scavenging acrolein and inhibiting neuronal activation. Pain Physician 15, 311-326.

Baños, M., Arellano-Mendoza, M. G., Vargas-Robles, H., Avila-Casado, M. C., Soto, V., Romo, E., et al. (2011). Relationship between angiotensin II receptor expression and cardiovascular risk factors in Mexican patients with coronary occlusive disease. Exp. Mol. Pathol. 91, 478-483. doi: 10.1016/j.yexmp.2011.05.002

Baslund, B., Wiencke, A. K., Rasmussen, N., Faurschou, M., and Toft, P. B. (2012). Treatment of orbital inflammation with rituximab in Wegener's granulomatosis. Clin. Exp. Rheumatol. 30, S7-S10.

Belch, J. J., Topol, E. J., Agnelli, G., Bertrand, M., Califf, R. M., Clement, D. L., et al. (2003). Critical issues in peripheral arterial disease detection and management: a call to action. Arch. Intern. Med. 163, 884-892. doi: 10.1001/archinte.163.8.884

Bilecen, D., Schulte, A. C., Kaspar, A., Küstermann, E., Seelig, J., Elverfeldt, D., et al. (2003). Detection of the non-steroidal anti-inflammatory drug niflumic acid in humans: a combined 19F-MRS in vivo and in vitro study. NMR Biomed. 16, 144-151. doi: 10.1002/nbm.820

Björck, M., Lepkowska Eriksson, M., Bylock, A., Steuer, J., Wanhainen, A., Carlsson, B. C., et al. (2013). Plasminogen activator inhibitor-1 levels and
PAD patients. Based on the protein-protein interaction network PADPIN, we collected the binary relations between FDAapproved drugs and genes annotated in PADPIN. By gathering FDA-approved drugs, these predictions form a basis for further validation and future translational research in PAD.

\section{Acknowledgments}

LC, AP, and BA proposed the idea; LC implemented the simulation; LC, BA, and AP edited the paper. The research was supported by NIH grant HL101200 and R21 HL122721 (AP, BA) and 1UH3TR000959 (BA).

\section{Supplementary Material}

The Supplementary Material for this article can be found online at: http://journal.frontiersin.org/article/10.3389/fphar. 2015.00179 activity decrease after intervention in patients with critical limb ischaemia. Eur. J. Vasc. Endovasc. Surg. 46, 214-222. doi: 10.1016/j.ejvs.2013.05.011

Botti, C., Maione, C., Dogliotti, G., Russo, P., Signoriello, G., Molinari, A. M., et al. (2012). Circulating cytokines present in the serum of peripheral arterial disease patients induce endothelial dysfunction. J. Biol. Regul. Homeost. Agents 26, 67-79.

Buritova, J., and Besson, J. M. (1997). Potent anti-inflammatory/analgesic effects of lornoxicam in comparison to other nsaids: a c-fos study in the rat Inflammopharmacology 5, 331-341. doi: 10.1007/s10787-997-0030-9

Buritova, J., and Besson, J. M. (1998). Dose-related anti-inflammatory/analgesic effects of lornoxicam: a spinal c-Fos protein study in the rat. Inflamm. Res. 47, 18-25. doi: $10.1007 / \mathrm{s} 000110050245$

Cao, Z., Ding, X., Huang, Y., Liu, S., Lin, J., Lyu, H., et al. (2015). Etanercept inhibits synovial inflammation and reduces the expression of adhesion related molecules in synovial tissues of patients with rheumatoid arthritis. $\mathrm{Xi} B a \mathrm{Yu}$ Fen Zi Mian Yi Xue Za Zhi 31, 511-515.

Caracas, H. C., Maciel, J. V., Martins, P. M., de Souza, M. M., and Maia, L. C. (2009). The use of lidocaine as an anti-inflammatory substance: a systematic review. J. Dent. 37, 93-97. doi: 10.1016/j.jdent.2008.10.005

Chamian, F., Lowes, M. A., Lin, S. L., Lee, E., Kikuchi, T., Gilleaudeau, P., et al. (2005). Alefacept reduces infiltrating $T$ cells, activated dendritic cells, and inflammatory genes in psoriasis vulgaris. Proc. Natl. Acad. Sci. U.S.A. 102, 2075-2080. doi: 10.1073/pnas.0409569102

Chen, Y. F., Jobanputra, P., Barton, P., Bryan, S., Fry-Smith, A., Harris, G., et al. (2008). Cyclooxygenase-2 selective non-steroidal anti-inflammatory drugs (etodolac, meloxicam, celecoxib, rofecoxib, etoricoxib, valdecoxib and lumiracoxib) for osteoarthritis and rheumatoid arthritis: a systematic review and economic evaluation. Health Technol. Assess. 12, 1-278, iii. doi: $10.3310 /$ hta 12110

Chmiel, J. F., Konstan, M. W., Accurso, F. J., Lymp, J., Mayer-Hamblett, N., Vandevanter, D. R., et al. (2015). Use of ibuprofen to assess inflammatory biomarkers in induced sputum: implications for clinical trials in cystic fibrosis. J. Cyst. Fibros. doi: 10.1016/j.jcf.2015.03.007. [Epub ahead of print].

Choi, E. K., Kim, S. H., Kang, I. C., Jeong, J. Y., Koh, J. T., Lee, B. N., et al. (2013). Ketoprofen inhibits expression of inflammatory mediators in human dental pulp cells. J. Endod. 39, 764-767. doi: 10.1016/j.joen.2013.02.003

Chou, W. Y., Chuang, K. H., Sun, D., Lee, Y. H., Kao, P. H., Lin, Y. Y., et al. (2015). Inhibition of PKC-induced COX-2 and IL-8 expression in human breast cancer cells by glucosamine. J. Cell. Physiol. 230, 2240-2251. doi: 10.1002/jcp.24955

Chu, L. H., Lee, E., Bader, J. S., and Popel, A. S. (2014). Angiogenesis interactome and time course microarray data reveal the distinct activation patterns in endothelial cells. PLoS ONE 9:e110871. doi: 10.1371/journal.pone.01 10871 
Chu, L. H., Rivera, C. G., Popel, A. S., and Bader, J. S. (2012). Constructing the angiome: a global angiogenesis protein interaction network. Physiol. Genomics 44, 915-924. doi: 10.1152/physiolgenomics.00181.2011

Chu, L. H., Vijay, C. G., Annex, B. H., Bader, J. S., and Popel, A. S. (2015). PADPIN: protein-protein interaction networks of angiogenesis, arteriogenesis, and inflammation in peripheral arterial disease. Physiol. Genomics. 47, 331-343. doi: 10.1152/physiolgenomics.00125.2014

Cosio, B. G., Iglesias, A., Rios, A., Noguera, A., Sala, E., Ito, K., et al. (2009). Lowdose theophylline enhances the anti-inflammatory effects of steroids during exacerbations of COPD. Thorax 64, 424-429. doi: 10.1136/thx.2008.103432

Costa, D., Gomes, A., Lima, J. L., and Fernandes, E. (2008). Singlet oxygen scavenging activity of non-steroidal anti-inflammatory drugs. Redox Rep. 13, 153-160. doi: 10.1179/135100008X308876

Croner, R. S., Balzer, K., Schellerer, V., Müller, V., Schlabrakowsi, A., Sturzl, M., et al. (2012). Molecular characterization of peripheral arterial disease in proximal extremity arteries. J. Surg. Res. 178, 1046-1058. doi: 10.1016/j.jss.2012.07.024

Cudmore, L. A., Muurlink, T., Whittem, T., and Bailey, S. R. (2013). Effects of oral clenbuterol on the clinical and inflammatory response to endotoxaemia in the horse. Res. Vet. Sci. 94, 682-686. doi: 10.1016/j.rvsc.2013.01.003

Cunha, V. R., Izumi, C. M., Petersen, P. A., Magalhães, A., Temperini, M. L., Petrilli, H. M., et al. (2014). Mefenamic acid anti-inflammatory drug: probing its polymorphs by vibrational (IR and Raman) and solid-state NMR spectroscopies. J. Phys. Chem. B 118, 4333-4344. doi: 10.1021/jp500988k

da Cunha, V., Tham, D. M., Martin-McNulty, B., Deng, G., Ho, J. J., Wilson, D. W., et al. (2005). Enalapril attenuates angiotensin II-induced atherosclerosis and vascular inflammation. Atherosclerosis 178, 9-17. doi: 10.1016/j.atherosclerosis.2004.08.023

de Haro Miralles, J., Gónzalez, A. F., Varela Casariego, C., and Garcia, F. A. (2010). Onset of peripheral arterial disease: role of endothelin in endothelial dysfunction. Interact. Cardiovasc. Thorac. Surg. 10, 760-765. doi: 10.1510/icvts.2009.227967

de Visser, Y. P., Walther, F. J., Laghmani el, H., Boersma, H., van der Laarse, A., and Wagenaar, G. T. (2009). Sildenafil attenuates pulmonary inflammation and fibrin deposition, mortality and right ventricular hypertrophy in neonatal hyperoxic lung injury. Respir. Res. 10:30. doi: 10.1186/1465-9921-10-30

Donnenfeld, E. D., Nichamin, L. D., Hardten, D. R., Raizman, M. B., Trattler, W., Rajpal, R. K., et al. (2011). Twice-daily, preservative-free ketorolac $0.45 \%$ for treatment of inflammation and pain after cataract surgery. Am. J. Ophthalmol. 151, 420.e1-426.e1. doi: 10.1016/j.ajo.2010.09.003

Dudley, J. T., Deshpande, T., and Butte, A. J. (2011). Exploiting drug-disease relationships for computational drug repositioning. Brief. Bioinform. 12, 303-311. doi: 10.1093/bib/bbr013

Eby, G. (2005). Elimination of arthritis pain and inflammation for over 2 years with a single $90 \mathrm{~min}$, topical $14 \%$ gallium nitrate treatment: case reports and review of actions of gallium III. Med. Hypotheses 65, 1136-1141. doi: 10.1016/j.mehy.2005.06.021

Egido, J., and Ruiz-Ortega, M. (2007). Anti-inflammatory actions of quinapril. Cardiovasc. Drugs Ther. 21, 211-220. doi: 10.1007/s10557-007-6019-1

El Desoky, E. S. (2011). Drug therapy of heart failure: an immunologic view. Am. J. Ther. 18, 416-425. doi: 10.1097/MJT.0b013e3181d169db

Fehervari, M., Krepuska, M., Szeplaki, G., Apor, A., Sotonyi, P., Prohaszka, Z., et al. (2014). The level of complement C3 is associated with the severity of atherosclerosis but not with arterial calcification in peripheral artery disease. Int. Angiol. 33, 35-41.

Fernandes, J. L., de Oliveira, R. T., Mamoni, R. L., Coelho, O. R., Nicolau, J. C., Blotta, M. H., et al. (2008). Pentoxifylline reduces pro-inflammatory and increases anti-inflammatory activity in patients with coronary artery diseasea randomized placebo-controlled study. Atherosclerosis 196, 434-442. doi: 10.1016/j.atherosclerosis.2006.11.032

Flórez, A., de Haro, J., Martínez, E., Varela, C., Bleda, S., and Acín, F. (2009). Selective cyclooxygenase-2 inhibition reduces endothelial dysfunction and improves inflammatory status in patients with intermittent claudication. Rev. Esp. Cardiol. 62, 851-857. doi: 10.1016/s1885-5857(09)72649-0

Fox, S. M., and Johnston, S. A. (1997). Use of carprofen for the treatment of pain and inflammation in dogs. J. Am. Vet. Med. Assoc. 210, 1493-1498.

Francisci, D., Falcinelli, E., Baroncelli, S., Petito, E., Cecchini, E., Weimer, L. E., et al. (2014). Potential anti-inflammatory effects of maraviroc in HIV-positive patients: a pilot study of inflammation, endothelial dysfunction, and coagulation markers. Scand. J. Infect. Dis. 46, 466-470. doi: $10.3109 / 00365548.2014 .898332$

Frostegård, J. (2013). Immunity, atherosclerosis and cardiovascular disease. $B M C$ Med. 11:117. doi: 10.1186/1741-7015-11-117

Frumkin, L. R. (2012). The pharmacological treatment of pulmonary arterial hypertension. Pharmacol. Rev. 64, 583-620. doi: 10.1124/pr.111.005587

Fu, S., Zhao, H., Shi, J., Abzhanov, A., Crawford, K., Ohno-Machado, L., et al. (2008). Peripheral arterial occlusive disease: global gene expression analyses suggest a major role for immune and inflammatory responses. BMC Genomics 9:369. doi: 10.1186/1471-2164-9-369

Futosi, K., Németh, T., Pick, R., Vantus, T., Walzog, B., and Mócsai, A. (2012). Dasatinib inhibits proinflammatory functions of mature human neutrophils. Blood 119, 4981-4991. doi: 10.1182/blood-2011-07-369041

Gardner, A. W., Parker, D. E., Montgomery, P. S., Sosnowska, D., Casanegra, A. I., Esponda, O. L., et al. (2014). Impaired vascular endothelial growth factor A and inflammation in patients with peripheral artery disease. Angiology 65, 683-690. doi: $10.1177 / 0003319713501376$

Glaser, K. B., Carlson, R. P., Sung, A., Bauer, J., Lock, Y. W., Holloway, D., et al. (1993). Pharmacological characterization of WAY-121,520: a potent anti-inflammatory indomethacin-based inhibitor of 5-lipoxygenase (5LO)/phospholipase A2 (PLA2). Agents Actions 39 Spec No, C30-C32. doi: 10.1007/BF01972711

Goertz, O., Ring, A., Buschhaus, B., Hirsch, T., Daigeler, A., Steinstraesser, L., et al. (2011). Influence of anti-inflammatory and vasoactive drugs on microcirculation and angiogenesis after burn in mice. Burns 37, 656-664. doi: 10.1016/j.burns.2011.01.004

Goldfine, A. B., Silver, R., Aldhahi, W., Cai, D., Tatro, E., Lee, J., et al. (2008). Use of salsalate to target inflammation in the treatment of insulin resistance and type 2 diabetes. Clin. Transl. Sci. 1, 36-43. doi: 10.1111/j.1752-8062.2008.00026.x

Grisar, J. C., Haddad, F., Gomari, F. A., and Wu, J. C. (2011). Endothelial progenitor cells in cardiovascular disease and chronic inflammation: from biomarker to therapeutic agent. Biomark. Med. 5, 731-744. doi: 10.2217/bmm.11.92

Haas, T. L., Lloyd, P. G., Yang, H. T., and Terjung, R. L. (2017). Exercise training and peripheral arterial disease. Compr. Physiol. 2, 2933-3017. doi: 10.1002/cphy.c110065

Hacke, W., Kaste, M., Bluhmki, E., Brozman, M., Dávalos, A., Guidetti, D., et al. (2008). Thrombolysis with alteplase 3 to 4.5 hours after acute ischemic stroke. N. Engl. J. Med. 359, 1317-1329. doi: 10.1056/NEJMoa0804656

Hall, P. S., Hanby, A., and Cameron, D. A. (2009). Lapatinib for inflammatory breast cancer. Lancet Oncol. 10, 538-539. doi: 10.1016/S1470-2045(09) 70120-2

Hazarika, S., Farber, C. R., Dokun, A. O., Pitsillides, A. N., Wang, T., Lye, R. J., et al. (2013). MicroRNA-93 controls perfusion recovery after hindlimb ischemia by modulating expression of multiple genes in the cell cycle pathway. Circulation 127, 1818-1828. doi: 10.1161/CIRCULATIONAHA.112.000860

Heilman, R. L., Khamash, H. A., Smith, M. L., Chakkera, H. A., Moss, A. A., and Reddy, K. S. (2013). Delayed allograft inflammation following alemtuzumab induction for kidney transplantation. Clin. Transplant. 27, 772-780. doi: $10.1111 /$ ctr.12201

Herová, M., Schmid, M., Gemperle, C., Loretz, C., and Hersberger, M. (2014). Low dose aspirin is associated with plasma chemerin levels and may reduce adipose tissue inflammation. Atherosclerosis 235, 256-262. doi: 10.1016/j.atherosclerosis.2014.05.912

Hirono, K., Kemmotsu, Y., Wittkowski, H., Foell, D., Saito, K., Ibuki, K., et al. (2009). Infliximab reduces the cytokine-mediated inflammation but does not suppress cellular infiltration of the vessel wall in refractory Kawasaki disease. Pediatr. Res. 65, 696-701. doi: 10.1203/PDR.0b013e31819ed68d

Hirsch, A. T., Haskal, Z. J., Hertzer, N. R., Bakal, C. W., Creager, M. A., Halperin, J. L., et al. (2006). ACC/AHA Guidelines for the Management of Patients with Peripheral Arterial Disease (lower extremity, renal, mesenteric, and abdominal aortic): a collaborative report from the American Associations for Vascular Surgery/Society for Vascular Surgery, Society for Cardiovascular Angiography and Interventions, Society for Vascular Medicine and Biology, Society of Interventional Radiology, and the ACC/AHA Task Force on Practice Guidelines (writing committee to develop guidelines for the management of patients with peripheral arterial disease)-summary of 
recommendations. J. Vasc. Interv. Radiol. 17, 1383-1397; quiz 1398. doi: 10.1097/01.rvi.0000240426.53079.46

Hoier, B., Walker, M., Passos, M., Walker, P. J., Green, A., Bangsbo, J., et al. (2013). Angiogenic response to passive movement and active exercise in individuals with peripheral arterial disease. J. Appl. Physiol. (1985) 115, 1777-1787. doi: 10.1152/japplphysiol.00979.2013

Holgate, S., Casale, T., Wenzel, S., Bousquet, J., Deniz, Y., and Reisner, C. (2005). The anti-inflammatory effects of omalizumab confirm the central role of IgE in allergic inflammation. J. Allergy Clin. Immunol. 115, 459-465. doi: 10.1016/j.jaci.2004.11.053

Holgate, S., Smith, N., Massanari, M., and Jimenez, P. (2009). Effects of omalizumab on markers of inflammation in patients with allergic asthma. Allergy 64, 1728-1736. doi: 10.1111/j.1398-9995.2009.02201.x

Hong, Y. J., Jeong, M. H., Lee, S. R., Hong, S. N., Kim, K. H., Park, H. W., et al. (2007). Anti-inflammatory effect of abciximab-coated stent in a porcine coronary restenosis model. J. Korean Med. Sci. 22, 802-809. doi: 10.3346/jkms.2007.22.5.802

Hu, B. C., Li, Y., Liu, M., Sheng, C. S., and Wang, J. G. (2013). Anklebrachial index in relation to the natriuretic peptide system polymorphisms and urinary sodium excretion in Chinese. Atherosclerosis 230, 86-91. doi: 10.1016/j.atherosclerosis.2013.06.020

Hunter, M. R., Cahoon, W. D. Jr., and Lowe, D. K. (2013). Angiotensinconverting enzyme inhibitors for intermittent claudication associated with peripheral arterial disease. Ann. Pharmacother. 47, 1552-1557. doi: $10.1177 / 1060028013501803$

Jeon, J. W., Ha, U. H., and Paek, S. H. (2014). In vitro inflammation inhibition model based on semi-continuous toll-like receptor biosensing. PLoS ONE 9:e105212. doi: 10.1371/journal.pone.0105212

Jiang, A., Wang, J., Joshi, M., and Christoforidis, J. B. (2013). Systemic treatments for noninfectious vitreous inflammation. Mediators Inflamm. 2013:515312. doi: $10.1155 / 2013 / 515312$

Kapoor, R., and Huang, Y. S. (2006). Gamma linolenic acid: an antiinflammatory omega-6 fatty acid. Curr. Pharm. Biotechnol. 7, 531-534. doi: $10.2174 / 138920106779116874$

Keifer, J. A., Guttridge, D. C., Ashburner, B. P., and Baldwin, A. S. Jr. (2001). Inhibition of NF-kappa B activity by thalidomide through suppression of IkappaB kinase activity. J. Biol. Chem. 276, 22382-22387. doi: 10.1074/jbc.M100938200

Knox, C., Law, V., Jewison, T., Liu, P., Ly, S., Frolkis, A., et al. (2011). DrugBank 3.0: a comprehensive resource for 'omics' research on drugs. Nucleic Acids Res. 39, D1035-D1041. doi: 10.1093/nar/gkq1126

Konopatskaya, O., and Poole, A. W. (2010). Protein kinase Calpha: disease regulator and therapeutic target. Trends Pharmacol. Sci. 31, 8-14. doi: 10.1016/j.tips.2009.10.006

Kraan, M. C., van Kuijk, A. W., Dinant, H. J., Goedkoop, A. Y., Smeets, T. J., de Rie, M. A., et al. (2002). Alefacept treatment in psoriatic arthritis: reduction of the effector T cell population in peripheral blood and synovial tissue is associated with improvement of clinical signs of arthritis. Arthritis Rheum. 46, 2776-2784. doi: 10.1002/art.10543

Lapchak, P. A., and Araujo, D. M. (2007). Advances in ischemic stroke treatment: neuroprotective and combination therapies. Expert Opin. Emerg. Drugs 12, 97-112. doi: 10.1517/14728214.12.1.97

Le, D. E., Pascotto, M., Leong-Poi, H., Sari, I., Micari, A., and Kaul, S. (2013). Anti-inflammatory and pro-angiogenic effects of beta blockers in a canine model of chronic ischemic cardiomyopathy: comparison between carvedilol and metoprolol. Basic Res. Cardiol. 108, 384. doi: 10.1007/s00395-0130384-7

Lee, E., Fertig, E. J., Jin, K., Sukumar, S., Pandey, N. B., and Popel, A. S. (2014). Breast cancer cells condition lymphatic endothelial cells within pre-metastatic niches to promote metastasis. Nat. Commun. 5, 4715. doi: 10.1038/ncomms5715

Leite, L. M., Carvalho, A. G., Ferreira, P. L., Pessoa, I. X., Gonçalves, D. O., Lopes Ade, A., et al. (2011). Anti-inflammatory properties of doxycycline and minocycline in experimental models: an in vivo and in vitro comparative study. Inflammopharmacology 19, 99-110. doi: 10.1007/s10787-011-0077-5

Lippi, G., Mattiuzzi, C., and Favaloro, E. J. (2013). Novel and emerging therapies: thrombus-targeted fibrinolysis. Semin. Thromb. Hemost. 39, 48-58. doi: $10.1055 / \mathrm{s}-0032-1328935$
Liu, N., He, S., Tolbert, E., Gong, R., Bayliss, G., and Zhuang, S. (2012). Suramin alleviates glomerular injury and inflammation in the remnant kidney. PLoS ONE 7:e36194. doi: 10.1371/journal.pone.0036194

Lubamba, B., Huaux, F., Lebacq, J., Marbaix, E., Dhooghe, B., Panin, N., et al. (2012). Immunomodulatory activity of vardenafil on induced lung inflammation in cystic fibrosis mice. J. Cyst. Fibros. 11, 266-273. doi: 10.1016/j.jcf.2012.03.003

Luyt, C. E., Lepailleur-Enouf, D., Gaultier, C. J., Valdenaire, O., Steg, G., and Michel, J. B. (2000). Involvement of the endothelin system in experimental critical hind limb ischemia. Mol. Med. 6, 947-956.

Massaro, M., Scoditti, E., Carluccio, M. A., Pellegrino, M., Calabriso, N., Storelli, C., et al. (2013). Dipyridamole decreases inflammatory metalloproteinase- 9 expression and release by human monocytes. Thromb. Haemost. 109, 280-289. doi: 10.1160/TH12-05-0326

Masud, R., Shameer, K., Dhar, A., Ding, K., and Kullo, I. J. (2012). Gene expression profiling of peripheral blood mononuclear cells in the setting of peripheral arterial disease. J. Clin. Bioinforma. 2:6. doi: 10.1186/2043-9113-2-6

Merino, A., Alvarez-Lara, M. A., Ramirez, R., Carracedo, J., Martin-Malo, A., and Aljama, P. (2012). Losartan prevents the development of the pro-inflammatory monocytes CD14+CD16+ in haemodialysis patients. Nephrol. Dial. Transplant. 27, 2907-2912. doi: 10.1093/ndt/gfr767

Mladenova, D., Pangon, L., Currey, N., Ng, I., Musgrove, E. A., Grey, S. T., et al. (2013). Sulindac activates NF-kappaB signaling in colon cancer cells. Cell Commun. Signal. 11:73. doi: 10.1186/1478-811X-11-73

Moraes, B. M., do Amaral, B. C., Morimoto, M. S., Vieira, L. G., Perazzo, F. F., and Carvalho, J. C. (2007). Anti-inflammatory and analgesic actions of etoricoxib (an NSAID) combined with misoprostol. Inflammopharmacology 15, 175-178. doi: 10.1007/s10787-006-1581-x

Nagib, M. M., Tadros, M. G., Elsayed, M. I., and Khalifa, A. E. (2013). Antiinflammatory and anti-oxidant activities of olmesartan medoxomil ameliorate experimental colitis in rats. Toxicol. Appl. Pharmacol. 271, 106-113. doi: 10.1016/j.taap.2013.04.026

Nardi, M., Lobo, C., Bereczki, A., Cano, J., Zagato, E., Potts, S., et al. (2007). Analgesic and anti-inflammatory effectiveness of nepafenac $0.1 \%$ for cataract surgery. Clin. Ophthalmol. 1, 527-533.

Nimmerjahn, F., and Ravetch, J. V. (2008). Anti-inflammatory actions of intravenous immunoglobulin. Annu. Rev. Immunol. 26, 513-533. doi: 10.1146/annurev.immunol.26.021607.090232

Norgren, L., Hiatt, W. R., Dormandy, J. A., Nehler, M. R., Harris, K. A., Fowkes, F. G., et al. (2007). Inter-society consensus for the management of peripheral arterial disease (TASC II). Eur. J. Vasc. Endovasc. Surg. 33(Suppl. 1), S1-S75. doi: 10.1016/j.ejvs.2006.09.024

Ostchega, Y., Paulose-Ram, R., Dillon, C. F., Gu, Q., and Hughes, J. P. (2007). Prevalence of peripheral arterial disease and risk factors in persons aged 60 and older: data from the National Health and Nutrition Examination Survey 19992004. J. Am. Geriatr. Soc. 55, 583-589. doi: 10.1111/j.1532-5415.2007.01123.x

Pammolli, F., Magazzini, L., and Riccaboni, M. (2011). The productivity crisis in pharmaceutical R\&D. Nat. Rev. Drug Discov. 10, 428-438. doi: 10.1038/nrd3405

Pan, W. Z., Shi, C. X., Tian, M., and Yu, J. G. (2014). Anti-CD11c antibody, Efalizumab attenuate ventilator-induced lung injury. Eur. Rev. Med. Pharmacol. Sci. 18, 2182-2190.

Papaliodis, G. N., Chu, D., and Foster, C. S. (2003). Treatment of ocular inflammatory disorders with daclizumab. Ophthalmology 110, 786-789. doi: 10.1016/S0161-6420(02)01932-2

Paravastu, S. C., Mendonca, D. A., and Da Silva, A. (2013). Beta blockers for peripheral arterial disease. Cochrane Database Syst. Rev. 9, CD005508. doi: 10.1002/14651858.CD005508.pub3

Pardi, D. S., Loftus, E. V. Jr., and Camilleri, M. (2002). Treatment of inflammatory bowel disease in the elderly: an update. Drugs Aging 19, 355-363. doi: 10.2165/00002512-200219050-00004

Pyriochou, A., Vassilakopoulos, T., Zhou, Z., and Papapetropoulos, A. (2007). cGMP-dependent and -independent angiogenesis-related properties of nitric oxide. Life Sci. 81, 1549-1554. doi: 10.1016/j.lfs.2007.09.014

Rahman, S. T., Lauten, W. B., Khan, Q. A., Navalkar, S., Parthasarathy, S., and Khan, B. V. (2002). Effects of eprosartan versus hydrochlorothiazide on markers of vascular oxidation and inflammation and blood pressure (reninangiotensin system antagonists, oxidation, and inflammation). Am. J. Cardiol. 89, 686-690. doi: 10.1016/S0002-9149(01)02340-2 
Rajpal, R. K., Ross, B., Rajpal, S. D., and Hoang, K. (2014). Bromfenac ophthalmic solution for the treatment of postoperative ocular pain and inflammation: safety, efficacy, and patient adherence. Patient Prefer. Adherence 8, 925-931. doi: 10.2147/PPA.S46667

Rice, T. W., and Bernard, G. R. (2004). Drotrecogin alfa (activated) for the treatment of severe sepsis and septic shock. Am. J. Med. Sci. 328, 205-214. doi: 10.1097/00000441-200410000-00003

Ridker, P. M., and Lüscher, T. F. (2014). Anti-inflammatory therapies for cardiovascular disease. Eur. Heart J. 35, 1782-1791. doi: 10.1093/eurheartj/ehu203

Ridker, P. M., Thuren, T., Zalewski, A., and Libby, P. (2011). Interleukin-1beta inhibition and the prevention of recurrent cardiovascular events: rationale and design of the Canakinumab Anti-inflammatory Thrombosis Outcomes Study (CANTOS). Am. Heart J. 162, 597-605. doi: 10.1016/j.ahj.2011. 06.012

Rossetti, R. G., Seiler, C. M., Brathwaite, K., and Zurier, R. B. (1995). Effect of misoprostol on acute and chronic inflammation. Am. J. Ther. 2, 600-606. doi: 10.1097/00045391-199509000-00004

Rowbotham, M. C., Davies, P. S., Verkempinck, C., and Galer, B. S. (1996). Lidocaine patch: double-blind controlled study of a new treatment method for post-herpetic neuralgia. Pain 65, 39-44. doi: 10.1016/0304-3959(95) 00146-8

Rozovski, U., Keating, M. J., and Estrov, Z. (2013). Targeting inflammatory pathways in chronic lymphocytic leukemia. Crit. Rev. Oncol. Hematol. 88, 655-666. doi: 10.1016/j.critrevonc.2013.07.011

Rull, A., García, R., Fernández-Sender, L., Beltrán-Debón, R., Aragonès, G., Alegret, J. M., et al. (2011). The role of combined assessment of defense against oxidative stress and inflammation in the evaluation of peripheral arterial disease. Curr. Mol. Med. 11, 453-464. doi: 10.2174/1566524117962 68713

Sahara, M., Sata, M., Morita, T., Nakajima, T., Hirata, Y., and Nagai, R. (2010). A phosphodiesterase-5 inhibitor vardenafil enhances angiogenesis through a protein kinase G-dependent hypoxia-inducible factor-1/vascular endothelial growth factor pathway. Arterioscler. Thromb. Vasc. Biol. 30, 1315-1324. doi: 10.1161/ATVBAHA.109.201327

Saito, T., Hojo, Y., Ogoyama, Y., Hirose, M., Ikemoto, T., Katsuki, T., et al. (2012). S100A12 as a marker to predict cardiovascular events in patients with chronic coronary artery disease. Circ. J. 76, 2647-2652. doi: 10.1253/circj.CJ-12-0093

Shahin, Y., Barnes, R., Barakat, H., and Chetter, I. C. (2013). Metaanalysis of angiotensin converting enzyme inhibitors effect on walking ability and ankle brachial pressure index in patients with intermittent claudication. Atherosclerosis 231, 283-290. doi: 10.1016/j.atherosclerosis.2013. 09.037

Shameer, K., Readhead, B., and Dudley, J. T. (2015). Computational and experimental advances in drug repositioning for accelerated therapeutic stratification. Curr. Top. Med. Chem. 15, 5-20. doi: 10.2174/1568026615666150 112103510

Shetty, N., and Derk, C. T. (2011). Endothelin receptor antagonists as disease modifiers in systemic sclerosis. Inflamm. Allergy Drug Targets 10, 19-26. doi: $10.2174 / 187152811794352088$

Shiono, T., Kodama, M., Hanawa, H., Fuse, K., Yamamoto, T., and Aizawa, Y. (2002). Suppression of myocardial inflammation using suramin, a growth factor blocker. Circ. J. 66, 385-389. doi: 10.1253/circj.66.385

Shiotsu, Y., Mori, Y., Hatta, T., Maki, N., Iida, K., Matsuoka, E., et al. (2011). Plasma S100A12 levels and peripheral arterial disease in end-stage renal disease. Nephron Extra 1, 242-250. doi: 10.1159/000335198

Shmilovich, H., Ben-Shoshan, J., Tal, R., Afek, A., Barshack, I., MayselAuslander, S., et al. (2009). B-type natriuretic peptide enhances vasculogenesis by promoting number and functional properties of early endothelial progenitor cells. Tissue Eng. Part A 15, 2741-2749. doi: 10.1089/ten.tea.20 08.0414

Signorelli, S. S., Fiore, V., and Malaponte, G. (2014). Inflammation and peripheral arterial disease: the value of circulating biomarkers (Review). Int. J. Mol. Med. 33, 777-783. doi: 10.3892/ijmm.2014.1657

Smoot, M. E., Ono, K., Ruscheinski, J., Wang, P. L., and Ideker, T. (2011). Cytoscape 2.8: new features for data integration and network visualization. Bioinformatics 27, 431-432. doi: 10.1093/bioinformatics/ btq 675
Stati, T., Musumeci, M., Maccari, S., Massimi, A., Corritore, E., Strimpakos, G., et al. (2014). beta-Blockers promote angiogenesis in the mouse aortic ring assay. J. Cardiovasc. Pharmacol. 64, 21-27. doi: 10.1097/FJC.00000000000 00085

Sun, J., Wu, Y., Xu, H., and Zhao, Z. (2012). DTome: a web-based tool for drug-target interactome construction. BMC Bioinformatics 13(Suppl. 9):S7. doi: 10.1186/1471-2105-13-S9-S7

Szubert, M., Suzin, J., Duechler, M., Szulawska, A., Czyz, M., and KowalczykAmico, K. (2014). Evaluation of selected angiogenic and inflammatory markers in endometriosis before and after danazol treatment. Reprod. Fertil. Dev. 26, 414-420. doi: 10.1071/RD12258

Taguchi, I., Toyoda, S., Takano, K., Arikawa, T., Kikuchi, M., Ogawa, M., et al. (2013). Irbesartan, an angiotensin receptor blocker, exhibits metabolic, antiinflammatory and antioxidative effects in patients with high-risk hypertension. Hypertens. Res. 36, 608-613. doi: 10.1038/hr.2013.3

Tang, E. H., Libby, P., Vanhoutte, P. M., and Xu, A. (2012). Anti-inflammation therapy by activation of prostaglandin EP4 receptor in cardiovascular and other inflammatory diseases. J. Cardiovasc. Pharmacol. 59, 116-123. doi: 10.1097/FJC.0b013e3182244a12

Thomas, G. W., Rael, L. T., Shimonkevitz, R., Curtis, C. G., Bar-Or, R., and BarOr, D. (2007). Effects of danazol on endothelial cell function and angiogenesis. Fertil. Steril. 88, 1065-1070. doi: 10.1016/j.fertnstert.2006.11.179

Topol, E. J., Smith, J., Plow, E. F., and Wang, Q. K. (2006). Genetic susceptibility to myocardial infarction and coronary artery disease. Hum. Mol. Genet. 15 Spec No 2, R117-R123. doi: 10.1093/hmg/ddl183

Varela, C., de Haro, J., Bleda, S., Rodriguez-Padilla, J., Ferruelo, A., and Acín, F. (2015). Circulating anti-beta2-glycoprotein I antibodies of peripheral arterial disease patients trigger a genomic overexpression of Toll-like receptor 4 in endothelial cells. J. Vasc. Surg. 61, 1041.e1-1049.e1. doi: 10.1016/j.jvs.2013.11.066

Varma, A., Das, A., Hoke, N. N., Durrant, D. E., Salloum, F. N., and Kukreja, R. C. (2012). Anti-inflammatory and cardioprotective effects of tadalafil in diabetic mice. PLoS ONE 7:e45243. doi: 10.1371/journal.pone.0045243

Wang, Y., Li, Y., Shen, Q., Li, X., Lu, J., Li, X., et al. (2014). Valsartan blocked alcohol-induced, Toll-like receptor 2 signaling-mediated inflammation in human vascular endothelial cells. Alcohol. Clin. Exp. Res. 38, 2529-2540. doi: 10.1111/acer.12532

Weyrich, A. S., Denis, M. M., Kuhlmann-Eyre, J. R., Spencer, E. D., Dixon, D. A., Marathe, G. K., et al. (2005). Dipyridamole selectively inhibits inflammatory gene expression in platelet-monocyte aggregates. Circulation 111, 633-642. doi: 10.1161/01.CIR.0000154607.90506.45

Whirl-Carrillo, M., McDonagh, E. M., Hebert, J. M., Gong, L., Sangkuhl, K., Thorn, C. F., et al. (2012). Pharmacogenomics knowledge for personalized medicine. Clin. Pharmacol. Ther. 92, 414-417. doi: 10.1038/clpt.2012.96

Williams, C., Panaccione, R., Ghosh, S., and Rioux, K. (2011). Optimizing clinical use of mesalazine (5-aminosalicylic acid) in inflammatory bowel disease. Therap. Adv. Gastroenterol. 4, 237-248. doi: 10.1177/1756283X11405250

Wozniak, K., Sleszycka, J., Safianowska, A., Wiechno, W., and Domagala-Kulawik, J. (2012). Systemic inflammation in peripheral arterial disease with or without coexistent chronic obstructive pulmonary disease: analysis of selected markers. Arch. Med. Sci. 8, 477-483. doi: 10.5114/aoms.2012.29525

Writing Group, M., Lloyd-Jones, D., Adams, R. J., Brown, T. M., Carnethon, M., Dai, S., et al. (2010). Heart disease and stroke statistics-2010 update: a report from the American Heart Association. Circulation 121, e46-e215. doi: 10.1161/CIRCULATIONAHA.109.192667

Yan, S. H., Zhao, N. W., Zhu, X. X., Wang, Q., Wang, H. D., Fu, R., et al. (2013). Benazepril inhibited the NF-kappaB and TGF-beta networking on LV hypertrophy in rats. Immunol. Lett. 152, 126-134. doi: 10.1016/j.imlet.2013.05.005

Yang, M., Cao, L., Xie, M., Yu, Y., Kang, R., Yang, L., et al. (2013). Chloroquine inhibits HMGB1 inflammatory signaling and protects mice from lethal sepsis. Biochem. Pharmacol. 86, 410-418. doi: 10.1016/j.bcp.2013.05.013

Yasar, A. S., Erbay, A. R., Ayaz, S., Turhan, H., Metin, F., Ilkay, E., et al. (2007). Increased platelet activity in patients with isolated coronary artery ectasia. Coron. Artery Dis. 18, 451-454. doi: 10.1097/MCA.0b013e3282a 30665

Yu, C., Gong, R., Rifai, A., Tolbert, E. M., and Dworkin, L. D. (2007). Long-term, high-dosage candesartan suppresses inflammation and injury in chronic kidney 
disease: nonhemodynamic renal protection. J. Am. Soc. Nephrol. 18, 750-759. doi: 10.1681/ASN.2006070770

Zachman, A. L., Wang, X., Tucker-Schwartz, J. M., Fitzpatrick, S. T., Lee, S. H., Guelcher, S. A., et al. (2014). Uncoupling angiogenesis and inflammation in peripheral artery disease with therapeutic peptide-loaded microgels. Biomaterials 35, 9635-9648. doi: 10.1016/j.biomaterials.2014.08.011

Ziche, M., Morbidelli, L., Masini, E., Amerini, S., Granger, H. J., Maggi, C. A., et al. (1994). Nitric oxide mediates angiogenesis in vivo and endothelial cell growth and migration in vitro promoted by substance P. J. Clin. Invest. 94, 2036-2044. doi: $10.1172 /$ JCI117557
Conflict of Interest Statement: The authors declare that the research was conducted in the absence of any commercial or financial relationships that could be construed as a potential conflict of interest.

Copyright (C) 2015 Chu, Annex and Popel. This is an open-access article distributed under the terms of the Creative Commons Attribution License (CC BY). The use, distribution or reproduction in other forums is permitted, provided the original author(s) or licensor are credited and that the original publication in this journal is cited, in accordance with accepted academic practice. No use, distribution or reproduction is permitted which does not comply with these terms. 